\title{
Applicability of Malaysian Standards and Universal Design in Public Buildings in Putrajaya
}

\author{
Syazwani Abdul Kadir, Mariam Jamaludin \\ Faculty of Architecture, Planning \& Surveying, \\ Universiti Teknologi MARA, Malaysia \\ syazwani@uwalumni.com
}

\begin{abstract}
This paper discusses an on-going research on universal design implementation in public buildings in Putrajaya with the applicability to Malaysian Standards of accessibility. The areas of study include disability and accessibility issues, current accessibility system in Malaysia, Malaysian Standards and universal design implementation in built environment, and the importance of public buildings in Putrajaya. Site observation involving facilities measurement and photographic documentation was conducted in ßve signißcant public buildings in this city. The ßndings of this study may be used as reference to designers and building managements in providing adequate accessible facilities for the buildings' visitors.

Keywords: persons with disabilities, Malaysian Standards of accessibility, barrier-free/universal design

eISSN 2514-751X @ 2018. The Authors. Published for AMER ABRA cE-Bs by e-International Publishing House, Ltd., UK. This is an open access article under the CC BY-NC-ND license (http://creativecommons.org/licenses/bync-nd/4.0/). Peer-review under responsibility of AMER (Association of Malaysian Environment-Behaviour Researchers), ABRA (Association of Behavioural Researchers on Asians) and cE-Bs (Centre for EnvironmentBehaviour Studies), Faculty of Architecture, Planning \& Surveying, Universiti Teknologi MARA, Malaysia.

DOI: https://doi.org/10.21834/aje-bs.v3i6.233
\end{abstract}




\subsection{Introduction}

Accessibility in built environment has been a significant issue discussed by architecture researchers as well as disability scholars around the world. Many studies stress on the vulnerability of inaccessible environment to the disabled people which highlights the importance of barrier-free environment in today's world (Carr, Francis, Rixlin and Stone, 1992; Zola, 1993; Chapireau and Colvez, 1998; Antonak and Livneh, 2000; Haq, 2003; Putnam, Greenen, Powers, Saxton, Finney and Dautel, 2003; Metts, 2004). Numerous studies which assess the design for less-able group in architecture have also been conducted in many countries including Malaysia (Blanck, Schur, Kruse, Schwochan and Song, 2003; Darcy and Harris 2003; Kozey and Das, 2004; Thapar, Warner, Drainoni, Williams, Ditchfield, Wierbicky and Nesathurai, 2004; Wiman and Sandhu, 2004; Head and Baker, 2005; Abdul Rahim, 2006; Saito, 2006; Rashid, Hussain and Yusuff, 2008; Abd Shukor and Othman, 2010; Jamaludin, Mohd Ali and Mohamad, 2010). These studies have contributed to the improvement of global accessibility system in developed countries as well as developing countries.

Malaysia has also shown some developments in catering the need of persons with disabilities (PWD). Nevertheless, as appealed by Kamal Malhotra, the United Nations Resident Coordinator, in the National Conference on "Accessibility and Universal Design: Implicationsfor Public Transport and the Built Environment", yet, there are the need to efficiently implement universal design in Malaysia, the need for more professionals or researchers in this area, and the need to revisit the current standardscodes (Malhotra, 2010). Thus, this study is called to enhance and complement the precedent studies that have been done on Malaysian accessibility issues and universal design implementation in public buildings.

The present study assessed the design of accessibility in five significant public buildings of different functions in Putrajaya, using design requirements from the current Malaysian Standards for accessibility; MS 1184: 2002 Code of Practice on Access for Disabled People to Public Buildings, and MS 1331:1993 Code of Practice on Access for Disabled People Outside Buildings; as well as universal design principles. The purpose was to identify whether the accessibility facilities in those public buildings meet the design requirements and guidelines of current Malaysian Standards and universal design principles.

\subsection{Literature Review}

\subsection{Disability and Accessibility Issues}

Based on the International Classification of Functioning, Disability and Health (ICF), World Health Organization (WHO) defines disability as "the outcome or result of a complex relationship between an individual's health condition and personal factors, and the external factors that represent the circumstances in which the individual lives" (2010). The ICF adopt social model inaddition to themedical model into its disability components, as illustrated in Table 1. 
Table 1: Overview of the ICF Components

\begin{tabular}{|c|c|c|c|c|}
\hline & $\begin{array}{l}\text { Body Function } \\
\text { and Structures }\end{array}$ & Activities & Participation & Contextual Factors \\
\hline $\begin{array}{c}\text { Level of } \\
\text { Functioning }\end{array}$ & ly (body parts) & $\begin{array}{l}\text { Individual (person } \\
\text { as a whole) }\end{array}$ & $\begin{array}{l}\text { ociety (life } \\
\text { situations) }\end{array}$ & $\begin{array}{l}\text { Environmental } \\
\text { Factors(external influence on } \\
\text { functioning) } \\
+ \\
\text { Personal Factors (internal } \\
\text { influence on functioning) }\end{array}$ \\
\hline Characteristics & \begin{tabular}{|l|} 
Body function \\
Body structure
\end{tabular} & $\begin{array}{l}\text { Performance of } \\
\text { individual's } \\
\text { activities }\end{array}$ & $\begin{array}{l}\text { Involvement in life } \\
\text { situations }\end{array}$ & $\begin{array}{l}\text { Features of the physical, social, } \\
\text { and attitudinal world + } \\
\text { Attributes of the person }\end{array}$ \\
\hline $\begin{array}{l}\text { Positive Aspects } \\
\text { (Functioning) }\end{array}$ & $\begin{array}{l}\text { Functional and } \\
\text { structural integrity }\end{array}$ & yActivity & Participation & Facilitators \\
\hline $\begin{array}{l}\text { Negative Aspects } \\
\text { (Disability) }\end{array}$ & Impairment & Activity limitation & $\begin{array}{l}\text { articipation } \\
\text { restriction }\end{array}$ & Barriers / hindrances \\
\hline
\end{tabular}

(Source: WHO, 1999)

Social model views the exclusion of disabled people from the mainstream as the result of public stereotype and ignorance of their rights and capabilities (Antonak and Livneh, 2000; Meyers, Anderson, Miller, Shipp and Hoenig, 2002; Putnam et al, 2003; Wiman and Sandhu, 2004), inadequate employment opportunity (Jenaro, Mank, Bottomley, Doose, \& Tuckerman, 2002), ignorance in the policy making system (Bickenbach et al., 1999; Metts, 2004), and the physical barriers they encounter in built environment (Wiman and Sandhu, 2004). In short, disability is caused by the complex relations between human and the environment, whichconsist of the various elements of surrounding culture, society, politic, climate, topography, technology and architecture (Meyers et al., 2002). From the social model, it is evident that barrier in architecture is one of the significant factors that contribute to disability situation of persons with impairments. Equally important, Imrie and Hall (2001) argue that policies, practices, and values of professionals who create the built environment are the main contributors to the barriers in architecture.

\subsection{Current Accessibility System in Malaysia}

Malaysian current disability and accessibility system has shown many improvements since last decades, namely by newly enacted regulations. On November 2001 for instance, the Ministry of Human Resources has established the Code of Practice of Employment of Disabled Person in Private Sector to increase job opportunities for PWD (Baharin, 2008). Malaysia has 
also established the firstright-based legislation for people with disabilities, entitled Persons with Disabilities Act in 2008 (Abd Shukor and Othman, 2010). With the enforcement of this Act, government wishes to provide PWD with better public transport facility, amenities and services, better health, education, information and technology, habilitation and rehabilitation, employment opportunities, as well as improved access to sports, leisure and cultural life activities.

Nonetheless, even with the growing numbers of accessibility regulations passed in this nation, the number of existing public buildings that have done modifications as approved by the standards codes is very few (Chen et al., 2007). In addition, some of the modifications are not correctly built according to the codes; therefore they are risky to the users. For examples, the disabled toilet doors that are supposed to open to the outside are mistakenly installed the other way around, and ramps are built too steep (Mahyuni, 2008). Other than the weak lawenforcement and negative publicresponse, Malaysianaccessibility systemalsoneeds to be refined due to the increasing number of registered PWD in Malaysia. According to the Department of Social Welfare (2010), the registered persons with disability in Malaysia have increased from 197,517 persons in 2006 to 248,858 person in 2008. The number is expected to increase over time, thus, it is crucial to form a more efficient accessibility system in Malaysia.

\subsection{Malaysian Standards and Universal Design Implementation in Built Environment}

The evaluation instruments of this research include Malaysian Standards for accessibility and universal design. To date, there are three current accessible design standards in Malaysia; MS 1184: 2002 Code of Practice on Access for Disabled Persons to Public Building (FirstRevision); MS 1331: 2003 Code of Practice for Access of Disabled Persons Outside Buildings (First Revision); and MS 1183: 1990 Specification for Fire Precautions in the Design and Construction of Buildings Part 8: Code of Practice for Means of Escape for Disabled People. Standards provide approved guidelines for the design of accessible facilities and detailed specifications that are too intricate to be included in codes regulations.

In addition to Malaysian Standards, universal design is also used as an evaluation instruments of this research because it covers broader range of users. College of Design, North Carolina University (1997) defines Universal Design as the design of products and environment which is usable by all people, to the greatest extent possible, without specialized design for certain group of people. The universal design's objective is to not demystify people's impairment, but rather to avoid such attention to their impairments and minimize public tendency to 'social ostracism' (Imrie and Hall, 2001). It is essential to adapt universal design principles in Malaysian accessibility system so that this nation is in line with other developed countries which provide accessible technologies that efficiently cater the need of all range of users. The seven principles of universal design are described in Table 3 below:

Table 2: The Key Principles of Universal Design

\begin{tabular}{|l|l|}
\hline Principle & Description \\
\hline Equitable Use & letopeoplewithdiverse abilities. \\
\hline
\end{tabular}


Abdul Kadir, S. \& Jamaludin, M. / Asian Journal of Environment-Behaviour Studies (ajE-Bs), 3(6) Jan / Feb 2018 (p.29-38)

\begin{tabular}{|c|c|}
\hline Flexibility in Use & The design accommodates a wide range of individual preferences and abilities \\
\hline imple and Intuitive Use & $\begin{array}{r}\text { Use of the designiseasyto understand, regardless ofthe user's experience, knowledge } \\
\text { language skills, or current concentration level }\end{array}$ \\
\hline Perceptible Information & $\begin{array}{r}\text { The design communicates necessary information effectively to the user, regardless o } \\
\text { ambient conditions or the user's sensory abilities }\end{array}$ \\
\hline Tolerance for Error & gn minimizes hazards and the adverse consequences of accident or unintended actions \\
\hline Low Physical Effort & The designcan be used efficiently and comfortably and with a minimum of fatigue \\
\hline $\begin{array}{l}\text { Size and Space for Approach } \\
\text { and Use }\end{array}$ & $\begin{array}{r}\text { Appropriate size and space is provided for approach, reach, manipulation, and use } \\
\text { regardless of user's body size, posture, or mobility }\end{array}$ \\
\hline
\end{tabular}

(Source: College of Design, North Carolina University)

\subsection{The Importance of Public Buildings in Putrajaya}

Malaysian government's decision to built Putrajaya was done to improve quality urban living and environment in the capital city, Kuala Lumpur, and Klang Valley area, by decentralizing the traffic congestion problem and high land value (John, 2006; Siong, 2006). A survey study on residents' perception of Putrajaya identity found that most respondents indicated buildings as the unique symbols and distinctive identity to Putrajaya (Ismail, Shamsuddin and Sulaiman, 2008). This shows that architecture is the main attraction to the city tourists as well as the residents, thus, it is significant to ensure that public buildings in Putrajaya are userfriendly and free from barriers that may hinder such development of city.

Other than the "Garden, Intelligent City" theme, the city planning was also driven by a "caring society" program which emphasizes on security and barrier-free environment for all. In response to the "caring society" program, Siong (2006) establishes that all buildings in Putrajaya was designed in the accordance to several Malaysian Standards for accessibility; MS1184:1991 Code of Practice on Access for Disabled People to Public Buildings, and MS 1331:1993 Code of Practice on Access for Disabled People Outside Buildings. However, some revisions have been done to those standards since the first construction commenced in 1996. Therefore, by conducting this research, this study intend to evaluate the accessibility in several public buildings in Putrajaya with the revised MS 1184 and MS 1331, so that any improvements needed can be suggested for future modifications.

\subsection{Methodology}

The five public buildings being assessed in this study is chosen according to their significances to public, and the regularity of public visiting in a daily basis. These buildings 
are the Department of Immigration office, Perdana Leadership Foundation building, Putrajaya Hospital, Putrajaya International Convention Centre, and Tuanku Mizan Zainal Abidin Mosque. Each of them functions differently as a government administrative office, an educational foundation, a health service centre, a conference or event place, and a worshipping place.

This study's data collection involves site observation of the five public buildings. The main public facilities of each building; parking space, pedestrian walkways, guiding blocks, ramps, main entrance, doors and doorways, corridor and interior pathways, information counter, stairways, elevators, escalators, praying room and ablution area, building's signage, public restroom, and accessible restroom; are measured and evaluated using guidelines from the Malaysian Standards for accessibility; MS 1184: 2002 Code of Practice on Access for Disabled People to Public Buildings, and MS 1331:1993 Code of Practice on Access for Disabled People Outside Buildings; and universal design principles. The checklists of design requirements derived from MS codes and universal design principles are completed based on researcher's measurement and observation of those facilities. Photographic documentation is also taken for further analysis of the current facilities condition. The checklists and photographic documentations were then analyzed qualitatively.

\subsection{Results \& Discussions}

From site observation checklists, the accessible facilities provided in five buildings in Putrajaya was evaluated and summarized as in Table 4:

Table3: TheBuildings'EvaluationBasedonDesignRequirements from Ms and Universal Design Principles

\begin{tabular}{|c|l|l|l|l|l|l|l|l|l|l|l|l|l|l|l|l|}
\hline Buildings & (a) & (b) & (c) & (d) & (e) & (f) & (g) & (h) & (i) & (j) & (k) & (l) & (m) & (n) & (o) & $\begin{array}{c}\text { Score } \\
\text { (out of75) }\end{array}$ \\
\hline $\begin{array}{c}\text { Department of } \\
\text { Immigration }\end{array}$ & & & & & & & & & & & & & & & 57 \\
\hline $\begin{array}{c}\text { Perdana Leadership } \\
\text { Foundation }\end{array}$ & & & & & & & & & & & & & 60 \\
\hline Putrajaya Hospital & & & & & & & & & & & & & 51 \\
\hline PICC & & & & & & & & & & & & & & 61 \\
\hline $\begin{array}{c}\text { Tuanku Mizan } \\
\text { Mosque }\end{array}$ & & & & & & & & & & & & & 60 \\
\hline
\end{tabular}

\section{Legend:}

\section{Parking Space}

(f) Doors and Doorways

(k) Escalators

\section{Pedestrian Walkways}

(g) Corridor and Interior Pathways

(I) Praying Room and Ablution Area 


\section{Guiding Blocks}

(h) Information Counter

(m)verall Building's Signage

\section{Ramps/ Foot Ramps}

(i) Stairways

(n) Public Restroom

\section{Main Entrance}

(j) Elevators/Lifts

(o) Accessible Restroom

\begin{tabular}{|l|l|l|}
\hline Score & Description \\
\hline 5 & All requirements met/ Facility is not provided but it is not necessary \\
\hline 4 & Most of the requirements met \\
\hline 3 & Equal proportion of requirements met and not met \\
\hline 2 & Most of the requirements are not met \\
\hline 1 & otprovidedeventhoughitis necessary \\
\hline
\end{tabular}

Among the five buildings, result shows that PICC (scored 61 points over 75) provides better accessibility to public, followed by Tuanku Mizan Mosque (60/75), Perdana Leadership Foundation (60/75), Department of Immigration (57/75), and lastly Putrajaya Hospital (51/75). PICC, Tuanku Mizan Mosque, and Perdana Leadership Foundation meet all the design requirements for $46.67 \%$ of their main public facilities, while Department of Immigration and Putrajaya Hospital recorded $33.33 \%$ and $26.67 \%$ of their facilities that fulfill all the requirements. The red indicators show Putrajaya Hospital verified to $26.67 \%$ of facilities that do not meet all the design requirements, higher than Department of Immigration with $13.33 \%$ while the other three buildings do not meet all the design requirements for only one out of the fifteen facilities being evaluated in these buildings. From the result, it is also shown that main entrance provides the most excellent accessibility in all five buildings while the poorest accessibility is recorded for information counter.

In general, major flaws in terms of the accessibility found from this study are shown in the design of guiding blocks, information counter, and ablution area. Guiding blocks are either not provided or incorrectly installed in the exterior area of these five buildings. For instances, guiding blocks with line and dot bearings were incorrectly installed at Tuanku Mizan Mosque and Departmentof Immigration building. Guiding blocks with line bearings are supposed to show the direction of pathways, however, at Tuanku Mizan Mosque, the lines direct to the wrong ways. Similarly inappropriate, the dot bearings which function as warning signal were installed as all guiding blocks at the Department of Immigration buildings, including guiding blocks that are supposed to show directions to the users. These incorrect installations may risk user's safety and confuse those who are in need of tactile indication to move around. In Putrajaya Hospital case, no guiding blocks are provided even though the parking space and pedestrian 
pathways are located quite a distance from the main entrance of the building.

Another facility that is lack of accessibility in this study is the information counter. All information counters except the ones in PICC and Putrajaya Hospital are too high for children or people on wheelchair to reach and do not provide space for wheelchair to roll under. This does not meet the design guidelines of MS and universal design which require appropriate height of counter and space underneath the work surface. Information counter is an important facility because it is the first place visitors may approach to get help or get information about the building way findings. If the counter is not reachable by some visitors, it may intimidate them and givenegative firstimpression of the accessibility of overall building interior.

Other than guiding blocks and information counter, ablution area is another facility with low accessibility found in this study. Ablution areas in all five buildings except Tuanku Mizan Mosque are built with level changes in front of the water faucets. This hinders less-able people such as wheelchair user, the elderly and crutches user to approach those faucets in order to clean themselves before performing pray. Tuanku MizanMosque shows the best solution for the design of accessible ablution area. With no level changes, the design manages to provide accessibility, yet ensure safety by using non-slippery materials for the floor finishes. The ablution areas in Tuanku Mizan Mosque are also provided with good lighting for users' ease of visual access while using the facility

\subsection{Conclusion and Recommendations}

Based on the overall findings, more than half of the main facilities provided in each assessed buildings of this study meet most of the design requirements from MS and universal design principles. Not much huge modifications need to be done to the facilities; however a small modification can contribute to large improvement to the buildings' overall accessibility. In Tuanku Mizan Mosque for example, the buildings doors and doorways can become perfectly accessible if all floor level changes or thresholds are made lower than $10 \mathrm{~mm}$. This may give a huge impact to the overall accessibility of the building because there are many unnecessary level changes more than $10 \mathrm{~mm}$ found in its interior. In addition, modifying this flaw will not impact the aesthetic value of the building's design so much. Other modifications for all buildings can be easily made to most of the facilities with low accessibility such as the guiding blocks, ramps, information counter and ablution area because these facilities are not structural compared to other facilities like stairways, elevators, and interior corridors.

Even though the overall accessibility for most buildings in this study shows satisfactory applicability of Malaysian Standards and universal design implementation, further analysis using different approaches such as facilities simulation, questionnaire survey tofacilities' users, and interviews with building managers are needed to strengthen and validate the research's methodology even more. Assessing the accessibility of public buildings in Putrajaya from different perspectives such as user's perception, building manager's view and user's experience may help finding other new and significant recommendations in ensuring a more barrier-free environment in the city. 


\section{References}

Abd Shukor, S. and Othman, N.A. (2010). Attitude of Event Organisers towards Disabled Attendees for the Development of Barrier-Free Tourism Events. The $5^{\text {th }}$ World Conference for Graduate Research in Tourism, Hospitality and Leisure, 25 - 30 May 2010, Cappadocia, Turkey, 634-649.

Abdul Rahim, A. (2006). Barrier Free Architecture from Islamic Perspective and Architecture for All, 13-15 June 2006, Renaissance Hotel, Kuala Lumpur.

Antonak, R.F. and Livneh, H. (2000). Measurement of Attitudes Towards Person with Disabilities. Disability and Rehabilitation, 22 (5), 211-224.

Baharin,F. (2008). Opening Speech by Fadilah Baharin, Director General of Standards Malaysia at the Asian Network on Consumer's Participation in Standardization (ANCO) Workshop, 16 February 2008, Petaling Jaya.

Bickenbach, J.E., Chatterji, S., Badley, E.M. \& Ustun, T.B. (1999). Models of Disablements, Universalism and the International Classification of Impairments, Disabilities and Handicaps. Social science \& Medicine, 48, 1173-1187.

Blanck, P., Schur, L., Kruse, D., Schwochan, S. and Song, C. (2003). Calibrating the Impact of the ADA's Employment Provisions. Stanford Law and Policy Review, 14 (2), 267-290.

Carr, S., Francis, M., Rixlin, L.G. and Stone, A.M. (1992). Environment and Behaviour Series Public Space. The Press Syndicate of the University of Cambridge, New York.

Chapireau, F. \& Colvez, A. (1998). Social Disadvantage in the International Classification of Impairments, Disabilities, and Handicap. Social Science and Medicine, 47 (1), 59-66.

Chen, R. K. et al. (2007). Rehabilitation Services and Education in Four Asian Countries: Thailand, South Korea, Singapore, and Malaysia. Rehabilitation Education, 21 (4), 231-240.

Darcy, S. and Harris, R. (2003). Inclusive and Accessible Special Event Planning: An Australian Perspective. Event Management, 8: 39-47.

Department of Social Welfare. Retrieved 28 December 2010, from http://www. jkm.gov.my.

Haq, F.S. (2003). Career and Employment Opportunities for Women with Disabilities in Malaysia. Asia Pacißc Disability Rehabilitation Journal, 14 (1), 71-78.

Head, L., Baker, P. (2005). Workplace accommodation ADA Title I: policy and the metrics of reasonable. Paper presented at the Technology and Persons with Disabilities Conference. Northridge, CA.

Imrie, R. and Hall, P. (2001). Inclusive Design: Designing and Developing Accessible Environments, Spoon Press, New York.

Ismail, I.S., Shamsuddin, S. and Sulaiman, A.B. (2008). An Evaluation of Residents Perception of Identity in Putrajaya New Town, Jurnal Alam Bina, 13(4).

Jamaludin, M., Mohd Ali, H. and Mohammad, E. (2010). Accessibility for Person with Disability in Tourism. The $5^{\text {th }}$ World Conference for Graduate Research in Tourism, Hospitality and Leisure, 25-30 May 2010, Cappadocia, Turkey, 383-394.

Jenaro, C., Mank, D., Bottomley, J., Doose, S. \& Tuckerman, P. (2002). Supported Employment in the International 
Context: An analysis of processes and outcomes. Journal of Vocational Rehabilitation, 17, 5-21.

John, J.I. (2006). The Planning of Putrajaya: Creating the Essence of Cities. Proceedings of the International Conference in the Built Environment in the $21^{\text {st }}$ Century (ICIBE 2006), 13-15 June 2006, Renaissance Kuala Lumpur Hotel, KL.

Kozey, J.W. \& Das, B. (2004). Determination of the Normal and Maximum Reach Measures of Adult Wheelchairs Users. International Journal of Industrial Ergonomics, 33, 205-213.

Mahyuni, E. (2008). Disabled Community Led Down by Authorities'Lack of Will, Poor Coordination. Komunitikini, 28 April, 2008. Retrieved 20 May 2010 from http://komuniti.malaysiakini.com.

Malhotra, K. (2010). Introductory Remarks of the National Conference on "Accessibility and Universal Design: Implications for Public Transport and the Built Environment”, 1 March 2010.

Metts, R. (2004). Disability and development. Background paper prepared for the Disability and Development Research Agenda Meeting, World Bank Headquarters, Washington D.C. 16 November 2004.

Meyers,A.R., Anderson, J.J.,Miller, D.R.,Shipp,K.\&Hoenig,H.(2002). Barriers, Facilitators, and Access for Wheelchair Users: Substantive and Methodologic Lessons from a Pilot Study of Environmental Effects. Social Science \& Medicine, 55, 1435-1446.

North Caroline State University, College of Design (1997). The Center for Universal Design, Retrieved 21 May 2010 from http://www.design.ncsu.edu/cud.

Putnam, M., Greenen, S., Powers, L., Saxton, M., Finney, S. and Dautel, P. (2003). Health and Wellness: People with disabilities discuss barriers and facilitators to well being. Journal of Rehabilitation, 69, 37-45.

Rashid, S.N.S.A., Hussain, M.R.H. \& Yusuff R.M. (2008). Designing Homes for the Elderly Based on the Anthropometry of Older Malaysians. Asian Journal of Gerontology Geriatrics, 3, 75-83.

Saito, Y.(2006). Awareness of UniversalDesignamong Facility Managersin Japan and the United States. Automation in Construction, 15, 462-478.

Siong, H.C. (2006). Lessons Learned from Planning of Putrajaya City - Administrative Centre of Malaysia. Seminar UTM-SIT workshop at Shibaura Institute, Japan, 14 December 2006

Thapar, N., Warner, G., Drainoni, M.L., William, S.R., Ditchfield, H., Wierbicky, J. and Nesathurai, S. (2004). A Pilot Study of Functional Access to Public Buildings and Facilities for Persons with Impairments. Disability and Rehabilitation, 26 (5), 280-289.

Wiman, R. \& Sandhu, J. (2004). Integrating Appropriate MeasuresforPeople with disabilitiesinthe Infrastructure Sector. Astudyin collaboration with Deutsche Gesellschaft fur Technische Zusammenarbeit (GTZ), the National Research and Development Centre for Welfare and Health in Finland (STAKES), and Inclusive Design Associates Limited (INDRA).

World Health Organization (2010), International Classification of Functioning, Disability and Health (ICF), Retrieved 28 December 2010 from http://www. who.int/classifications/icf/en/

Zola, I.K. (1993). Disability Statistics, What We Count and What It Tells Us: A personal and political analysis. Journal of Disability Policy Studies, 4, 9. 